preparation of a medicine or magic which will be so efficacious as to overcome the magic of the rain clouds, and cause them to give up their stores of water; for the August suns in the south-west are rapidly drying up the corn, which, without rain at this period of the vear, would be a failure. But when it is remembered that the Hopi live almost entirely upon vegetable products, of which corn forms almost 80 per cent., it will readily be understood that, should the combined efforts of the two sets of priests be not successful, famine must be the result. As each snake is released with a baho, it bears with it prayers which it is supposed to transmit to the great plumed serpent, who has influence with the rain gods of the four world quarters. It may be added that the fundamental element of nearly all Hopi ceremonies is the producion of a magic which will overcome the magic of the rain clouds.

So far as the writer is aware, no Hopi has ever died as a result of a snake-bite during these ceremonies. Nor has he ever seen a priest bitten by a snake. He is positive that nothing is done to render the snakes harmless. Nor do the Hopi have any antidote for the poison of the rattle- tion of not a few shows a marked approach to that charac teristic of the Cycads, the most primitive of existing seed plants. These plants, therefore, whilst retaining the outward form of ferns, are in reality transitional types. For convenience, these plants, which include the genera Heterangium, Lyginodendron, Medullosa, and many others, have been placed in a special group, the Cycadofilices or Fern-Cycads. The recognition of this group is one of the more interesting results that has accrued in recent years in fossil botany, and the view that the Cycadofilices are the remains of a natural bridge connecting the ferns and the Gymnosperms has received wide support.

In no case, however, had the fructification of any FernCycad been definitely recognised, hence it remained an open question whether the Cycadean advance which was so marked a feature of the vegetative organs found its counterpart in the reproductive process.

In the paper under notice the authors bring forward what they regard as adequate evidence for assigning a seed to Lyginodendron, perhaps the best known of all Cycadofilices, owing to its admirable preservation and very common

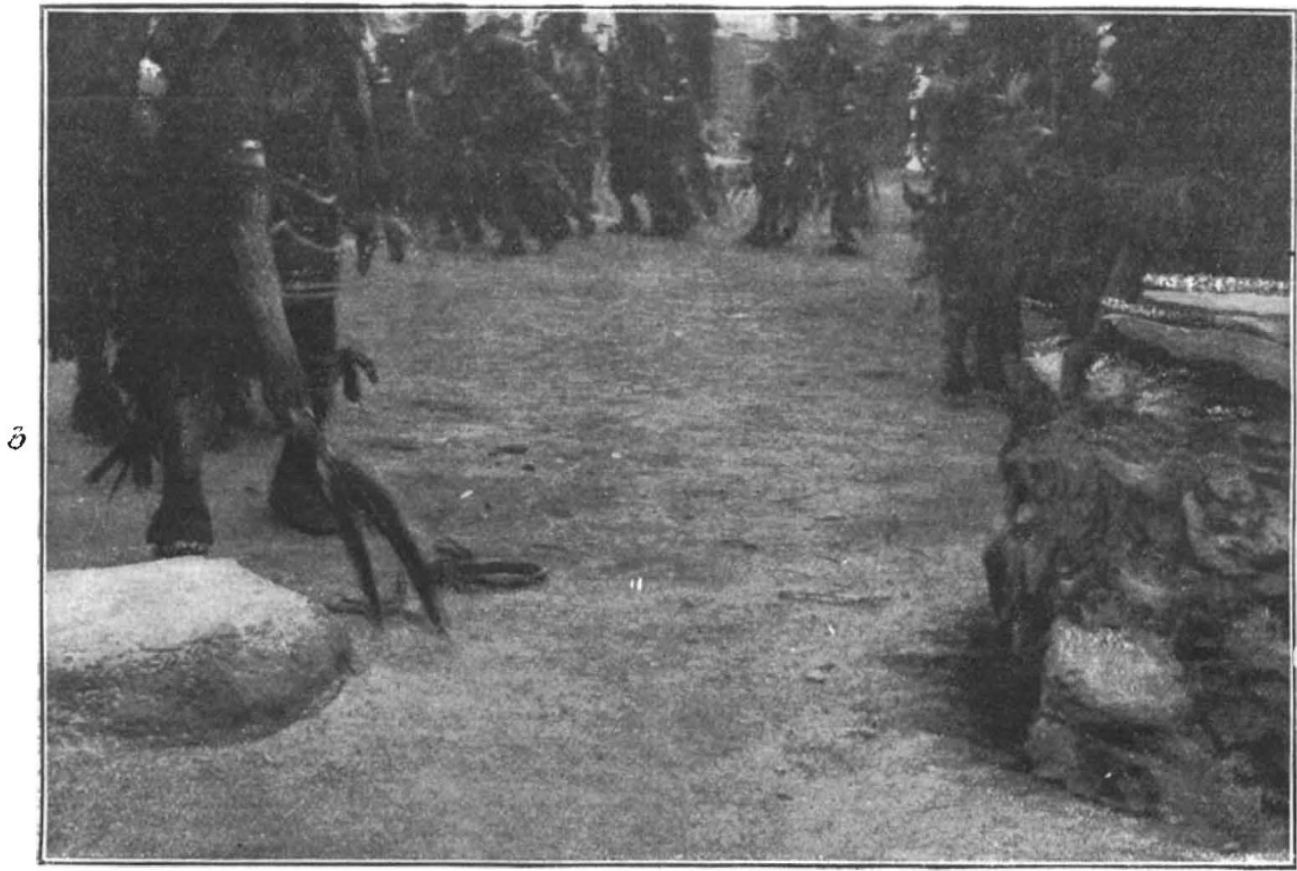

FIG. 3.-Priest using the Snake Whip preparatory to picking up a Snake.

snake. The Hopi seems thoroughly to understand the rattlesnake, and is cautious never to attempt to pick him up when in a coiled position. The Snake priest always carries with him his snake whip, which he shakes over the snake when coiled, as he is about to pick it up in the fields during the hunt, or in the kiva as he transfers it from the snake bag to the receptacle, or as he herds the snakes in the kiva, or picks them up on the plaza. Rarely is a snake seen coiled, its ambition being to escape.

George A. Dorsey.

\section{WERE THE FERN-CYCADS SEED-BEARING PLANTS?}

THIS was the burden of a prelininary paper read at the Royal Society on May 7 by Prof. F. W. Oliver and Dr. D. H. Scott, F.R.S., entitled "Lagenostoma Lomaxi, the seed of Lyginodendron."

During recent years the petrified remains of many fernlike plants from the Carboniferous rocks have received close attention, with the striking result that the internal organisa- occurrence in the calcareous nodules of the Lower Coalmeasures.

Numerous detached seeds are known from the Palæozoic rocks, but in no case has it been ascertained by what plants these seeds were borne, with the exception of certain forms which have been traced to the extinct family of the Cordaiteæ, and the curious seed-like fructifications of two Lycopods, Lepidocarpon and Miadesmia. The rest, although of great interest in the details of their organisation, have remained unassigned, being without traces of their origin, like fallen acorns in a forest.

In the case, however, of the seeds placed by Williamson in his genus Lagenostoma, a re-examination has revealed unexpected points of agreement between the structure of the envelopes of certain of these seeds, on the one hand, and the vegetative organs of Lyginodendron on the other. It appears that the seed named Lagenostoma Lomaxi after its discoverer, and occurring chiefly at Dulesgate, in Lancashire, is sometimes still attached to its pedicel, and is found enclosed in an envelope or cupule springing from the stalk just below the base of the seed, and extending above the micropyle, at least in young specimens. The cupule, in its relation to the seed, which is quite small,

No. I 753, voI.. 68] 
not larger than a pea, may be compared to the husk of a hazel-nut in miniature.

Both cupule and stalk bear numerous capitate glands, some stalked, others sessile, which present the closest agreement in size, form and structure with the glands which occur on the vegetative organs of Lyginodendron. It is the agreement between these glands, so close as to amount to identity, that forms the basis of the attribution of the seed to Lyginodendron. There is no other known plant from the Coal-measures with glands at all similar, nor is it likely that any unknown Gymnosperm should exactly resemble Lyginodendron in these characters. The vascular strands which traverse stalk and cupule present the closest agreement with those of Lyginodendron, and these and other characters go to strengthen the conclusion drawn from a comparison of the glands, and further support the attribution. The evidence will, of course, be weighed by botanists. Should it find acceptation, we have the following position. Lyginodendron, a fern-like plant with certain Cycadean characters, possessed seeds (on its leaves, so it may be inferred from the structure of the stalk and cupule) as fully characterised as those of any known Palæozoic gymnosperm. It retains, so far as its vegetative structure is concerned, the intermediate position already assigned to it, but whereas the fern-like characters have hitherto seemed to preponderate, the discovery of the seed inclines the balance strongly on the Gymnospermous side. The germ of the present discovery dates from the time when it became apparent on anatomical grounds that Lyginodendron was a transitional type. Dr. Scott in his published writings had already prepared the way, and the position now gained is the logical sequel. Nor is it likely that Lyginodendron stood alone; we must be prepared to find, what has long been recognised as a possibility, that many of the plants grouped under Cycadofilices already possessed seeds, and thus that a considerable proportion of the so-called "fernfronds " of the Palæobotanist realiy belonged to seed-bearing plants. The status of these "ferns" may be expected to take many years to unravel, owing to the difficulties that will be encountered in discriminating between such as bear true fern-sporangia and those the sporangia of which are really the pollen-sacs of Gymnospermous plants, and in allocating the numerous impressions which are quite sterile. It is premature to speculate how far back in the fern-series a seed habit obtained, but the results of further investigations in this field will be awaited with interest.

\section{"TABLOID" PREPARATIONS FOR} PHOTOGRAPHY.

THERE is probably no one who has reason occasionally to take a photograph, whether for simple pleasure or for scientific or business purposes, without having at command a well-equipped photographic laboratory, who does not consider the preparation of the various solutions required as a messy, troublesome and tedious performance. And the getting of some of the chemical substances in a fit state for use is a very real difficulty, only to be got over in some cases by procuring the original packages or bottles as issued by the manufacturer, and containing perhaps twenty times as much as is required. We have known several cases where so common a substance as sodium sulphite has been obtained only after seeking for it at several druggists, and other cases where the work was spoilt by reason of the gross impurity of the material.

These and similar difficulties are now matters of the past for those who use the "tabloid" preparations of Messrs. Burroughs, Wellcome and Co. Instead of a large bottle of stuff awkward to manipulate because either the substance is in hard lumps or light feathery crystals, one has a little bottle of little pills that need no weighing, because the contents of each are indicated on the label. In the majority of cases each tabloid has in it the quantity of material needed for one ounce of solution, so that any bulk can be made up without the possibility of error in calculation. The tabloids required are put into the measure glass, water added, stirred a little or crushed with a glass rod, and the solution is ready for use, with the advantage that it is fresh, and made with materials that can be relied on.
In many cases the requisite chemicals are mixed in the one tabloid, sulphite, alkali, and bromide, for example in developers, but there are no secret formulæ, as the contents of every tabloid are clearly set forth on the label. The formula, if necessary, can be modified to any extent by adding to it a tabloid of one or the other ingredients; or, if preferred, tabloids of simple unmixed substances may be used throughout.

So far as variety goes, practically everything that is required in photographic practice is supplied, including even such rarely used chemicals as potassium percarbonate and ammonium persulphate. There is a large selection for making gold baths for the toning of prints, and potassium ammonium chromate is supplied in 24-grain tabloids for sensitising carbon tissue. Ferrous oxalate and mercuric chloride are the only two omissions that we note; perhaps there is some difficulty with regard to these.

It appeared not unlikely that some of the chemicals might show signs of deterioration from their manipulation in the preparation of the tabloids, but those that we have tested have proved unexceptionable in quality. These preparations are worthy the attention of even the best equipped photographer working at home in his own laboratory, particularly with regard to the chemicals that are rarely required.

\section{A NEW INDEX OF APPLIED SCIENCE.}

WE have received a copy of the first issue of a new monthly periodical ${ }^{1}$ published at Brussels. The title, Index of the Technical Press, appears on it in the three languages French, English and German. The object of the publication is to supply a monthly index of articles of general interest appearing in the technical Press throughout the world, and giving the title with a brief explanation, the name of the author, the origin, the date of publication, and the length. In the case of articles appearing in the English, French, and German papers, these details are given in the languages in which they originally appeared. In the case of articles printed in other languages they are translated into French.

One very good characteristic of the publication is that it is printed on one side of the paper only, and in a convenient form for cutting out and pasting on cards for use in connection with card indices.

The publishers undertake to supply cuttings from the original papers of most of the articles indexed, at prices indicated by a letter affixed to each entry. Translations can also be obtained on a fixed scale. Such a publication should be of considerable value if the scheme is carried out with completeness, and the subscription price of five francs per annum is not a heavy one. Much, however, will depend on the interpretation given to the expression "general interest.'

The greater part of the issue is taken up with entries of engineering articles under various headings; some of these cover rather a wide field-electrical engineering, for example, forms one of the sections, without any subdivisions.

Besides engineering articles, there are sections devoted to statistics, political science, political economy, law, legislation and jurisprudence, administration, constabulary, insurance and partnership, commerce, communication and transport, mathematics, astronomy, physics, chemistry, geology, medicine. Various trades and manufactures are also included.

The "brief explanation" promised is confined to very slight extensions of the title in some cases, so that the only guide to the value of an article is the name of the author and that of the paper from which it is taken. This, however, if the indexing is really comprehensive, should be of considerable value, more especially with regard to subjects in which systematic abstracts are not obtainable.

Rather numerous errors are made in printing the English and German entries, especially in the former. They are not of a character to cause any inconvenience to those familiar with the languages, but they are unsightly, and their occurrence might easily be obviated by the employment of a proof reader familiar with the languages.

\section{G, W. DE T.}

1 Index of the Technical Press. (20 Rue de la Chancellerie, Brussels.)

NO. I753, VOL. 68] 